\title{
Purification of Deep Water in a Dam Lake Using Micro-Bubbles and/or Eco-Bio-Ring
}

\author{
M. Sadatomi, A. Kawahara, K. Kurogawa, and T. Akasaki
}

\begin{abstract}
This study is aiming at finding an efficient method to purify deep water in Midorikawa-dam Lake in Kumamoto Pref., Japan. The biological oxygen demand (BOD) of the water at first was $46 \mathrm{mg} / \mathrm{L}$ in the worst case. In the test, micro-bubbles were periodically supplied into the water in $80 \mathrm{~L}$ tank by a multi-fluids-mixer patented by Sadatomi and Kawahara. The bubbling rate were changed as $Q_{G}=1.0 \mathrm{~L} / \mathrm{min}$ and $2.0 \mathrm{~L} / \mathrm{min}$ to study its effect. In addition, the Eco-Bio-Ring including aerobic bacteria (Bacillus bacterium), sold by Big Bio Co. Ltd., Japan, were immersed in two tanks of the three in order to study its effect. As a result, it was cleared that $Q_{G}=1.0$ $\mathrm{L} / \mathrm{min}$ was enough to reduce the BOD to about $6-10 \mathrm{mg} / \mathrm{L}$ within two weeks, and the Eco-Bio-Ring was effective to reduce turbidity.
\end{abstract}

Index Terms-Aerobic bacteria, lake, micro-bubble, water purification.

\section{INTRODUCTION}

The micro-bubbles (MBs for short) have the following characteristics [1]:

1) Less than $100 \mathrm{~m}$ in size and very slow in rising velocity.

2) High pressure inside due to surface tension effects.

3) Large interfacial area concentration per unit volume.

4) High dissolubility in liquid.

Thus, they are reported to be useful in water purification, cultivation of fish and selfish, and healthcare, etc. [1], and extensively studied by mainly Japanese investigators, e.g., Kato et al. [2], Ohnari et al. [3], Takahashi et al. [4], Unger et al. [5], Terasaka et al. [6], Tamura et al. [7] together with us [8]-[10].

In water purification system such as sewage treatment plants in cities, bubbling by a porous aerator is commonly used to activate aerobic bacteria. The bubbles by such an aerator are bigger than a few millimeters, and the oxygen in air bubbles which can resolve in water is less than eight percent of that supplied, being inefficient. In order to efficiently resolve them, the bubble size is smaller the better [6], [8]-[10].

Sadatomi and Kawahara invented a multi-fluids-mixer [11] shown in Fig. 1. The mixer can generate fine bubbles called MBs in liquid pool by introducing liquid alone into the mixer, and gas is automatically sucked and broken into fine bubbles by a highly turbulent liquid flow. In the mixer used in this study, the diameters, $D$ and $d_{o}$, in Fig. 1 are $D=14.7$ $\mathrm{mm}, d_{o}=8.4 \mathrm{~mm}$, and the porosity of the porous ring is 25 $\mu \mathrm{m}$.

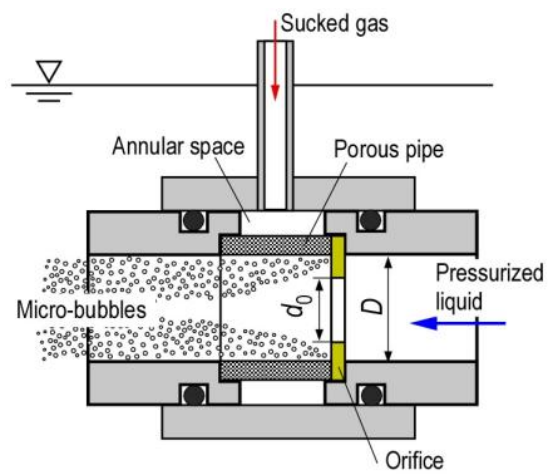

Fig. 1. Multi-fluids-mixer by Sadatomi and Kawahara [11]

Following to the above studies, the present study is motivated by the following request: Midorikawa is a river in Kumamoto pref. in Japan as shown in Fig. 2 (a), and was famous of very clean and a lot of sweetfish (called Ayu in Japan) before 1971 when a dam was constructed with a total storage capacity of $46 \times 10^{6} \mathrm{~m}^{3}$ as shown in Fig. 2 (b), (c).

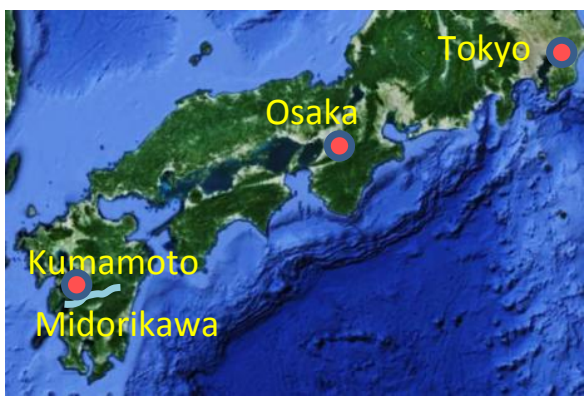

(a)

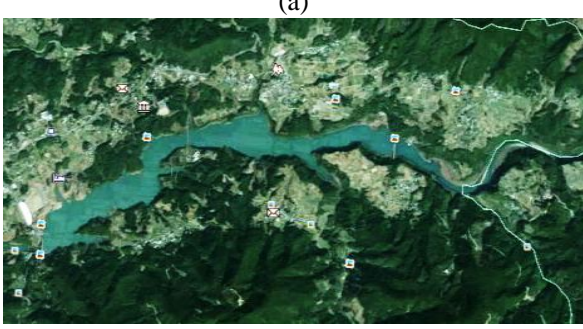

(b)

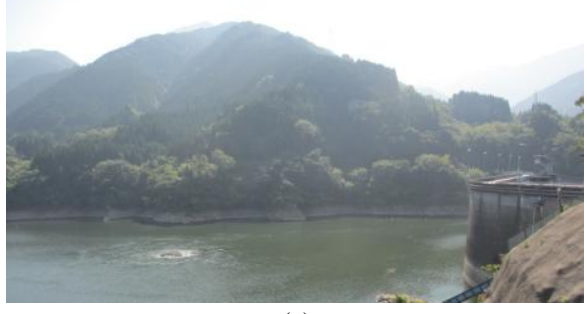

(c)

Fig. 2. Midorikawa-river and Midorikawa-dam Lake. 
Now a day, however, the water purity in the lake deteriorates to $19-46 \mathrm{mg} / \mathrm{L}$ in BOD and the number of sweet fish in the river downstream from the dam drastically decreases. So, the head of a fishermen's union in Midorikawa area asked us to find an efficient way to purify the water to a level less than $3 \mathrm{mg} / \mathrm{L}$ where the sweetfish can live based on the river standard in Ministry of the Environment in Japan. In order to respond the request, we conducted water purification tests in Kumamoto University. In the tests, micro-bubbles were periodically supplied by the multi-fluids-mixer into the $80 \mathrm{~L}$ deep water sampled from the Midorikawa-dam together with or without Eco-Bio-Ring (sold by Big Bio Co. Ltd., Japan) including aerobic bacteria (Bacillus bacterium) in order to study the effects of the bubbling and the addition of the Eco-Bio-Ring. In the present paper, a result of such water purification tests using micro-bubbles and Eco-Bio-Ring are reported together with the detailed structure and the performance of the mixer.

\section{EXPERIMENT}

\section{A. Experimental Apparatus and Test Condition}

Fig. 3 shows the apparatus for water the purification test. In the tests, three tanks was filled with $80 \mathrm{~L}$ deep water sampled from the Midorikawa-dam Lake, and periodic bubbling of MBs by the multi-fluids-mixer was done at $H=$ $0.4 \mathrm{~m}$ in depth with the aid of a timer for controlling the water pump. The water flow rate, $Q_{L}$, the bubbling rate, $Q_{G}$, and the water pressure, $p_{L}$, measured with the respective calibrated sensors were recorded in a personal computer via $\mathrm{A} / \mathrm{D}$ converter. The water flow rate was fixed at $Q_{L}=30 \mathrm{~L} / \mathrm{min}$ in order to make the micro-bubbles finer, while the bubbling rate was changed as $Q_{G}=1.0 \mathrm{~L} / \mathrm{min}$ and $2.0 \mathrm{~L} / \mathrm{min}$ in the two tanks in order to study the rate effects. Furthermore, the Eco-Bio-Ring including aerobic bacteria (Bacillus bacterium) was immersed at the bottom of the two tanks in order to study the effects of the addition of aerobic bacteria.

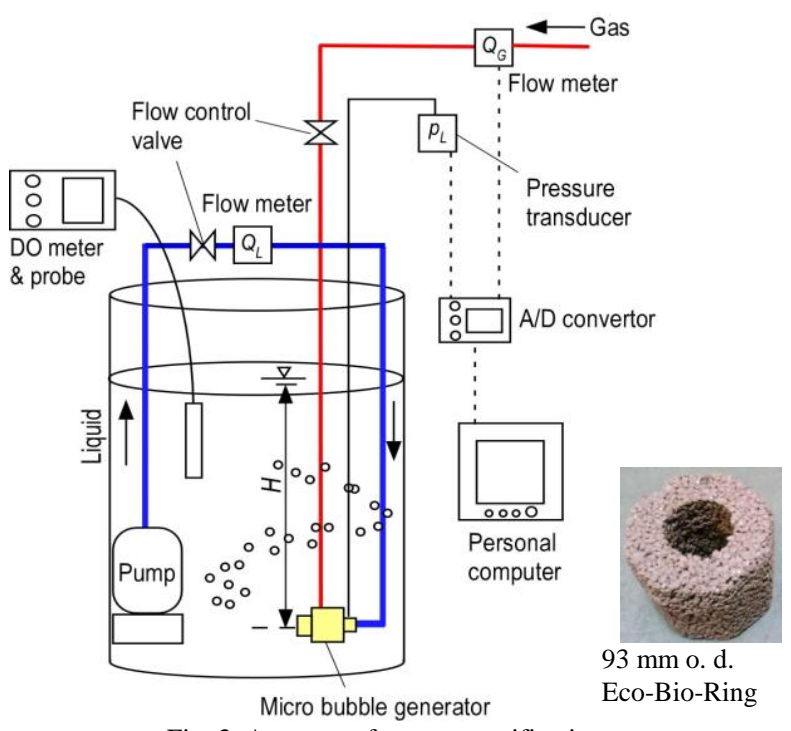

Fig. 3. Apparatus for water purification test.

The dissolved oxygen in water, DO, was measured every five minutes with a DO sensor immersed at $H=0.2 \mathrm{~m}$ in depth. The picture and the movie picture were taken from the outside of the transparent tank in order to monitor the bubbling and to measure the bubble diameter.

Table I lists the condition for the water purification test. $Q_{G}$ was set at $1.0 \mathrm{~L} / \mathrm{min}$ in tank 1 , while $2.0 \mathrm{~L} / \mathrm{min}$ in tanks 2 and 3. The Eco-Bio Ring was immersed in tanks 1 and 3, while not in tank 2. Thus, the effects of bubbling rate can be clarified from a comparison of the data between the tanks 1 and 3, while the effects of the Eco-Bio-Ring from the data between the tanks 2 and 3. Periodical bubbling of 40 minutes $\times 6$ times per day was conducted. Why 40 minutes is that the time required increasing DO to a saturated value of $8.5 \mathrm{mg} / \mathrm{L}$ was 30 minutes at $Q_{G}=1.0 \mathrm{~L} / \mathrm{min}$ as shown in Fig. 4 . The time became shorter with increasing of $Q_{G}$, but was not proportionally because the bubble diameter became larger with increasing of $Q_{G}$ as shown in Fig. 5. The bubbles smaller than $100 \mu \mathrm{m}$ was dominant at $Q_{G}=1.0 \mathrm{~L} / \mathrm{min}$, while those between 50 and $100 \mu \mathrm{m}$ at $Q_{G}=2.0$ and $4.0 \mathrm{~L} / \mathrm{min}$. The mean bubble diameter was $0.16 \mathrm{~mm}$ at $Q_{G}=1.0 \mathrm{~L} / \mathrm{min}$, while those at $Q_{G}=2.0$ and $4.0 \mathrm{~L} / \mathrm{min}$ were around $0.6 \mathrm{~mm}$.

TABLE I: CONDITION FOR WATER PURIFICATION TEST

\begin{tabular}{|c|c|c|c|c|}
\hline $\begin{array}{c}\text { Tank } \\
\text { No. }\end{array}$ & $\begin{array}{c}Q_{G} \\
\mathrm{~L} / \mathrm{min}\end{array}$ & $\begin{array}{c}Q_{L} \\
\mathrm{~L} / \mathrm{min}\end{array}$ & $\begin{array}{c}\text { Eco-Bio- } \\
\text { Ring }\end{array}$ & Bubbling time/day \\
\hline 1 & 1 & 30 & with & $40 \mathrm{~min} \times 6$ times \\
\hline 2 & 2 & 30 & without & $40 \mathrm{~min} \times 6$ times \\
\hline 3 & 2 & 30 & with & $40 \mathrm{~min} \times 6$ times \\
\hline
\end{tabular}

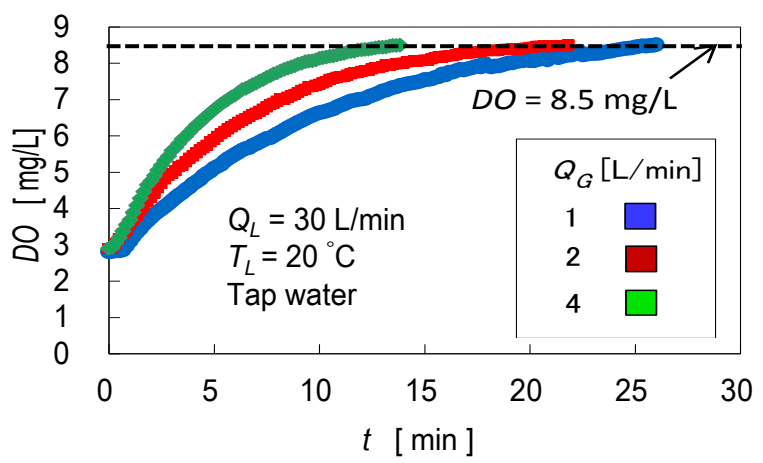

Fig. 4. Time variation data in DO in tap water.

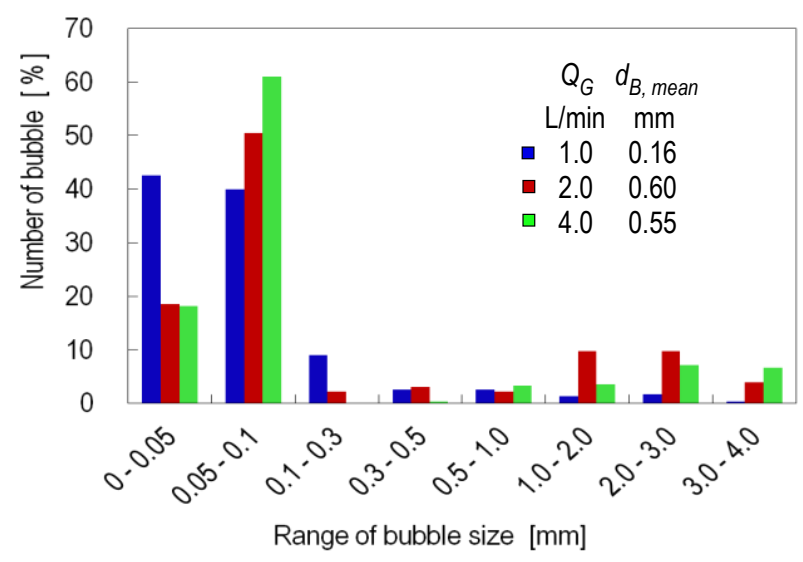

Fig. 5. Bubble diameter distribution.

\section{B. Measure of Water Purity in the Present Study}

As the measure of water purity, the biochemical oxygen demand, BOD, the chemical oxygen demand, COD, the turbidity, and $\mathrm{pH}$ were chosen in the present study. BOD is known as a measure of oxygen demand for bacteria to purify 
water. If BOD is high, aquatic organism such as fishes cannot live, thus BOD is an important factor for rivers. COD is known as a measure of oxygen demand for organic and inorganic substances to purify water. COD is an important factor for stagnant lakes and ponds. Turbidity is known as a measure of the concentration of suspended particles in water, and it decreases as the water purity increases.

Of these, COD, turbidity and $\mathrm{pH}$ were directly measured with the respective sensors, but BOD was indirectly by substituting measured DO data into Eq. (1):

$$
\mathrm{BOD}=\left(\mathrm{DO}_{0}-\mathrm{DO}_{5}\right) \times n_{D}
$$

Here, $\mathrm{DO}_{0}$ is the $\mathrm{DO}$ at the day measured and $\mathrm{DO}_{5}$ at five days after the day, $n_{D}$ is the degree of dilution.

Fig. 6 is an example of DO and temperature variation data in water under periodical bubbling of six times $\times 40$ min per day. The abscissa is the elapsed day from the day before the test. Although several data was not obtained in the second and fourth days due to a machine trouble, water temperature data shown as red curve do not change so much, but shows a small fluctuations depending upon whether the water pump is working or not to supply micro-bubbles. On the other side, DO data shown as blue curve changed very much: When micro-bubbles are supplied DO increases monotonically, while not supplied it decreases because the oxygen in water is consumed by the aerobic bacteria; Thus, there exists six times up and down every day; DO data shown as black curve as a moving averaged value decreases gradually in the first seven days probably due to the lack of oxygen supplied; the averaged DO data, however, rapidly increases on the eighth day and takes a constant value after the ninth day. Such a trend of the averaged DO data teaches us that the aerobic bacteria gradually increases and purifies water in the first seven days, and that the number of the aerobic bacteria after the eighth day decreases because the water does not contain feeds to increase it, i.e., the water becomes clean. Thus, the test water in Fig. 6 is considered to be almost purified within eight days bubbling with the aid of the Eco-Bio-Ring. In addition, such DO variation data must be a useful tool to judge whether the purification process is finished or not.

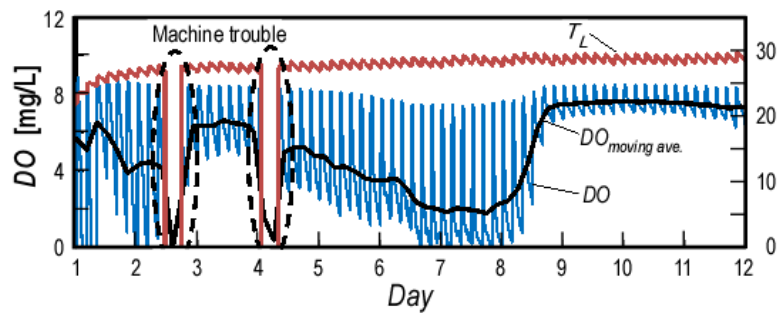

Fig. 6. Example of DO and temperature variation data in water under periodic bubbling of six times $\times 40$ min per day.

\section{ENVIRONMENTAL QUALITY STANDARDS FOR WATER POLLUTION IN JAPAN}

The Japanese Ministry of the Environment defined the environmental quality standard for water pollution, and shows in the website of http://www.env.go.jp/en/water/wq/wp.pdf. The standard consists of (a) Environmental quality standards for human health and (b) Environmental quality standards for conservation of the living environment, and the standard (b) consists of the standards of (1) Rivers (excluding Lakes), (2) Lakes (natural lakes and reservoirs that have 10 million cubic meters of water or more), and (3) Coastal water. Since the capacity of Midorikawa-dam Lake is 46 million cubic meters, the water quality there must satisfy the standard (2). In the standard (2), there are four levels from "AA" to " $\mathrm{C}$ ", and the second best level "A" fit well to the claim by the fisherman's union, as listed in Table II as the excerpt from the standard (2). In the standard (1), on the other hand, there are six levels from "AA" to "E", and the third best level "B" fit well to the claim by the fisherman's union, as listed in Table III as the excerpt from the standard (1). From Table II and Table III, we believe that the deep water in Midorikawa-dam Lake should satisfy $6.5<\mathrm{pH}<8.5$, COD and BOD $<3 \mathrm{mg} / \mathrm{L}, \mathrm{SS}<$ $5 \mathrm{mg} / \mathrm{L}, \mathrm{DO}>7.5 \mathrm{mg} / \mathrm{L}$, and Total coliform $<1000 \mathrm{MPN} / 100$ $\mathrm{mL}$. However, we have no Total coliform detector. In addition, we used a Turbidity detector which can detect suspended particles smaller than $1 \mathrm{~mm}$, instead of a SS detector which can detect 1 to $2 \mathrm{~mm}$ particles alone.

TABLE II: ENVIRONMENT QUALITY STANDARDS FOR CONSERVATION OF THE LIVING ENVIRONMENT FOR LAKES

\begin{tabular}{|c|c|c|c|c|c|c|}
\hline Level & Water use & $\mathrm{pH}$ & COD & SS & DO & $\begin{array}{l}\text { Total } \\
\text { coliform }\end{array}$ \\
\hline $\mathrm{A}$ & $\begin{array}{l}\text { Water supply } \\
\text { class } 2 \text { and } 3 \text {, } \\
\text { fishery class } 2 \text {, } \\
\text { bathing, and } \\
\text { uses listed in } \\
\text { B-C }\end{array}$ & $\begin{array}{c}6.5< \\
\mathrm{pH}< \\
8.5\end{array}$ & $\begin{array}{l}<3 \\
\mathrm{mg} / \mathrm{L}\end{array}$ & $\begin{array}{l}<5 \\
\mathrm{mg} / \mathrm{L}\end{array}$ & $\begin{array}{l}>7.5 \\
\mathrm{mg} / \mathrm{L}\end{array}$ & $\begin{array}{l}<\quad 1000 \\
\mathrm{MPN} / 100 \\
\mathrm{~mL}\end{array}$ \\
\hline
\end{tabular}

Notes:

Water supply class 2: Purify water using sedimentation filters and other ordinary means.

Water supply class 3: Purify water using pretreatment and other advanced method.

Fishery class 2: For such marine products inhabiting oligotrophic lakes as the Salmonidae (salmon/trout) species, sweetfish, and marine products for fishery class 3 .

TABLE III: ENVIRONMENT QUALITY STANDARDS FOR CONSERVATION OF THE LIVING ENVIRONMENT FOR RIVERS

\begin{tabular}{|c|c|c|c|c|c|c|}
\hline Level & Water use & $\mathrm{pH}$ & BOD & SS & DO & Total coliform \\
\hline B & $\begin{array}{l}\text { Water } \\
\text { supply class } \\
3 \text {, fishery } \\
\text { class } 2 \text {, and } \\
\text { uses listed } \\
\text { in C-E }\end{array}$ & $\begin{array}{l}6.5 \\
< \\
\mathrm{pH} \\
< \\
8.5\end{array}$ & $\begin{array}{l}<3 \\
\mathrm{mg} / \mathrm{L}\end{array}$ & $\begin{array}{l}<25 \\
\mathrm{mg} / \mathrm{L}\end{array}$ & $\begin{array}{l}>5 \\
\mathrm{mg} / \mathrm{L}\end{array}$ & $\begin{array}{ll}< & 5000 \\
\mathrm{MPN} / 100 \mathrm{~mL}\end{array}$ \\
\hline
\end{tabular}

Notes:

Fishery class 2: For such alpha-oligosaprobic marine products as the Salmonidae (salmon/trout) species, sweetfish, and marine products for fishery class 3 .

\section{WATER QUALiTy BEFORE WATER PURIFICATION TESTS}

Deep water was sampled twice from Midorikawa-dam Lake in a day before rainy season, and in a day after a heavy rain. These waters are called as the $1^{\text {st }}$ water and the $2^{\text {nd }}$ water. The quality of each water before the purification test is listed 
in Table IV, and the pictures of the $1^{\text {st }}$ water and the $2^{\text {nd }}$ water are shown in Fig. 7 (a) and Fig. 7 (b). The $1^{\text {st }}$ water is in a quality level in which it is not usable as a water supply for the living but usable as agricultural water. The $2^{\text {nd }}$ water was worse than the $1^{\text {st }}$ water as clearly seen from BOD and Turbidity data in Table IV and Fig. 7 (b), because it was contaminated with mud flown down along the mountain surface around the lake by the heavy rain.

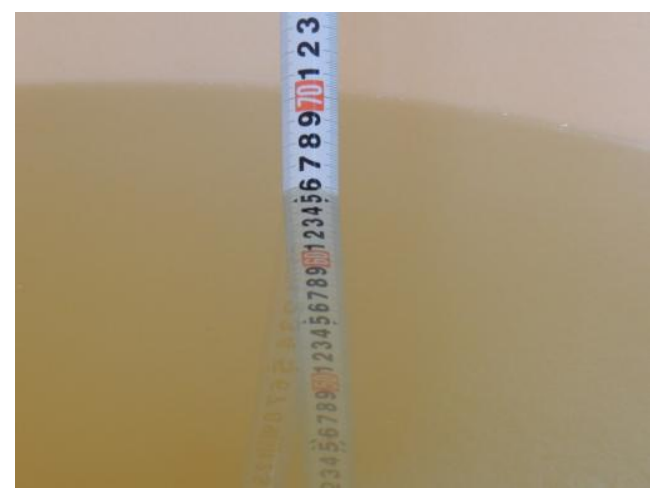

(a) $1^{\text {st }}$ water

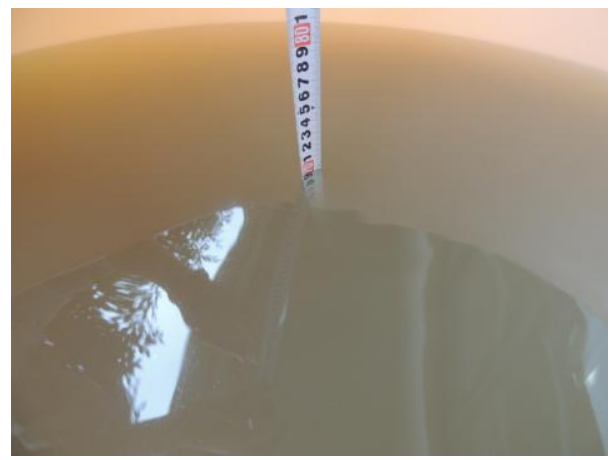

(b) $2^{\text {nd }}$ water

Fig. 7. Pictures of test waters before purification test.

TABLE IV: WATER QUALITY BEFORE PURIFICATION TESTS

\begin{tabular}{|l|l|l|l|l|l|}
\hline $\begin{array}{l}\text { Water name } \\
\text { (Sampled date) }\end{array}$ & $\begin{array}{c}\text { DO } \\
\mathrm{mg} / \mathrm{L}\end{array}$ & $\begin{array}{l}\text { BOD } \\
\mathrm{mg} / \mathrm{L}\end{array}$ & $\begin{array}{l}\text { COD } \\
\mathrm{mg} / \mathrm{L}\end{array}$ & $\begin{array}{l}\text { Turbidity } \\
\mathrm{mg} / \mathrm{L} \text { (PSL) }\end{array}$ & $\mathrm{pH}$ \\
\hline $\begin{array}{l}1^{\text {st }} \text { water } \\
\left(\text { June } 14^{\text {th }}, 2013\right)\end{array}$ & 5.8 & 19 & No data & 0.4 & 7.5 \\
\hline $\begin{array}{l}2^{\text {nd }} \text { water } \\
\left(\text { July } 1^{\text {st }}, 2013\right)\end{array}$ & 5.4 & 46 & 10 & 1.5 & 7.8 \\
\hline
\end{tabular}

\section{RESULTS AND DISCUSSIONS}

\section{A. Variation in Water Quality}

The variations in BOD, COD, Turbidity and $\mathrm{pH}$ during the purification test for the $2^{\text {nd }}$ water are shown respectively in Fig. 8 (a) to (d).

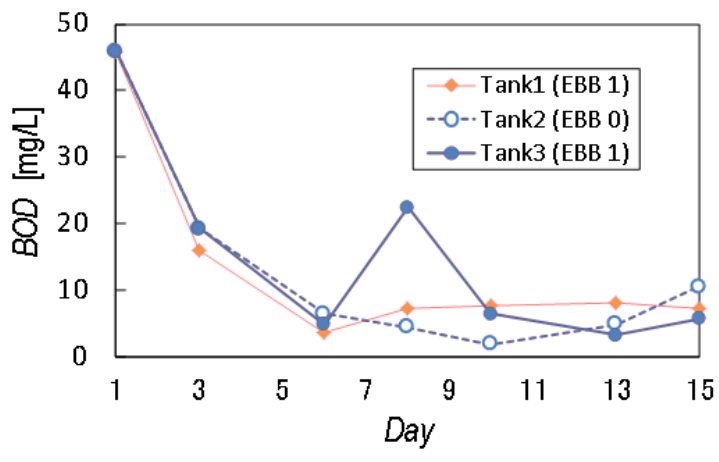

(a)

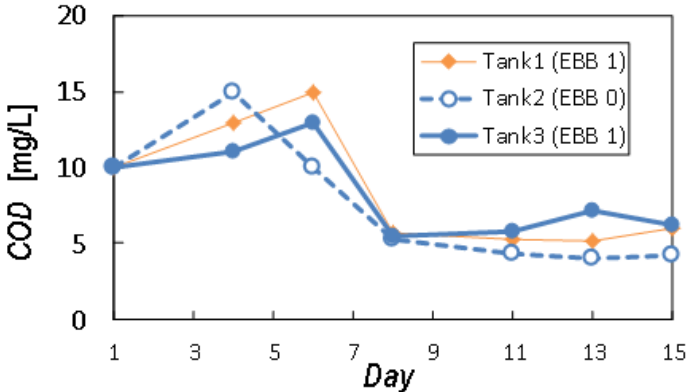

(b)

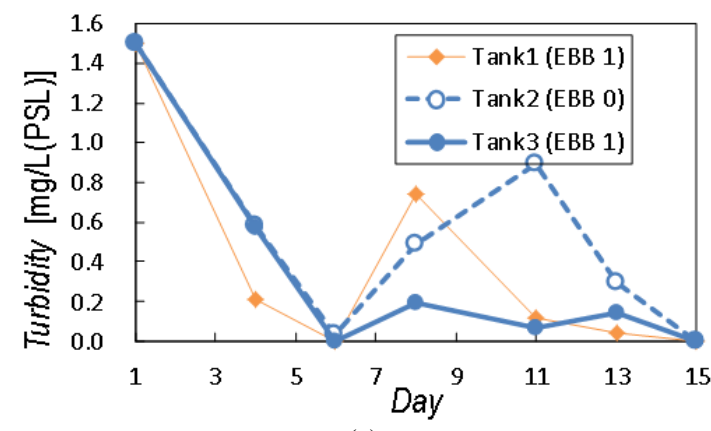

(c)

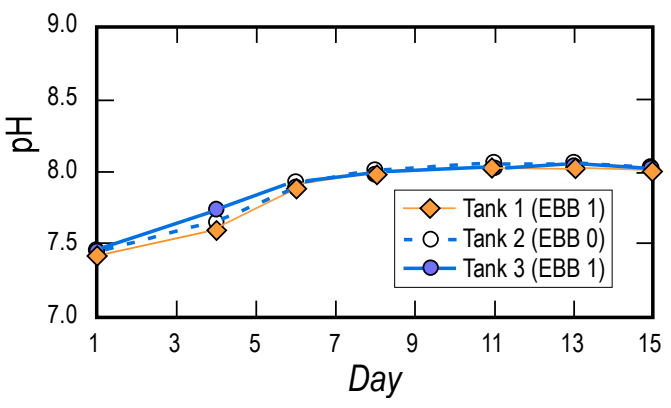

(d)

Fig. 8. Variations in water quality of the $2^{\text {nd }}$ water of Midorikawa-dam Lake during purification test.

BOD was rapidly decreased in the first six days and finally reduced to 5.6 to $10.4 \mathrm{mg} / \mathrm{L}$ on the last day, which is near to 3 $\mathrm{mg} / \mathrm{L}$, corresponding to the Fishery class 2 for rivers in the Japanese Environmental Quality Standard.

COD increased in the first four or six days probably due to the increase in the aerobic bacteria, but it decreased to about 5 $\mathrm{mg} / \mathrm{L}$ on the eighth day and finally to 4.2 to $6.2 \mathrm{mg} / \mathrm{L}$ on the last day, which is near to $3 \mathrm{mg} / \mathrm{L}$, corresponding to the level A for lakes in the Japanese Environmental Quality Standard.

Turbidities of water in three tanks were decreased to about zero in the first 5 days, but they mysteriously increased to 0.8 or 0.9 without tank 3 probably due to the floatation of very fine sediments deposited on the tank bottom. As seen from Fig. 9 (a) and (b), the transparency of water in the last day was superior in Tank 3 to Tank 2. Thus, we can conclude that the Eco-Bio-Ring is effective to decrease the turbidity.

TABLE V: WATER QUALITY BEFORE AND AFTER PURIFICATION TESTS

\begin{tabular}{|c|c|c|c|c|c|}
\hline $\begin{array}{c}\text { Water name } \\
\text { (Sampled date) }\end{array}$ & $\begin{array}{l}\text { DO } \\
\mathrm{mg} / \mathrm{L}\end{array}$ & $\begin{array}{c}\text { BOD } \\
\mathrm{mg} / \mathrm{L}\end{array}$ & $\begin{array}{c}\text { COD } \\
\mathrm{mg} / \mathrm{L}\end{array}$ & $\begin{array}{c}\text { Turbidity } \\
\mathrm{mg} / \mathrm{L}(\mathrm{PSL})\end{array}$ & $\mathrm{pH}$ \\
\hline $1^{\text {st }}$ water & 5.8 & 19 & No data & 0.4 & 7.5 \\
$\left(\right.$ June $\left.14^{\text {th }}, 2013\right)$ & $7.4-8.2$ & $4-8$ & No data & 0 & 7.8 \\
\hline $2^{\text {nd }}$ water & 5.4 & 46 & 10 & 1.5 & 7.5 \\
$\left(\right.$ July $\left.1^{\text {st }}, 2013\right)$ & $7.0-7.8$ & $6-10$ & $4-6$ & 0 & 8.0 \\
\hline
\end{tabular}

Table V summarize water quality data before and after the twice water purification tests. We can conclude from the $1^{\text {st }}$ and the $2^{\text {nd }}$ water purification tests, that the deep water in 
Midorikawa-dam Lake can be purified nearly to the level A for lakes in Japanese Environmental Quality Standard.

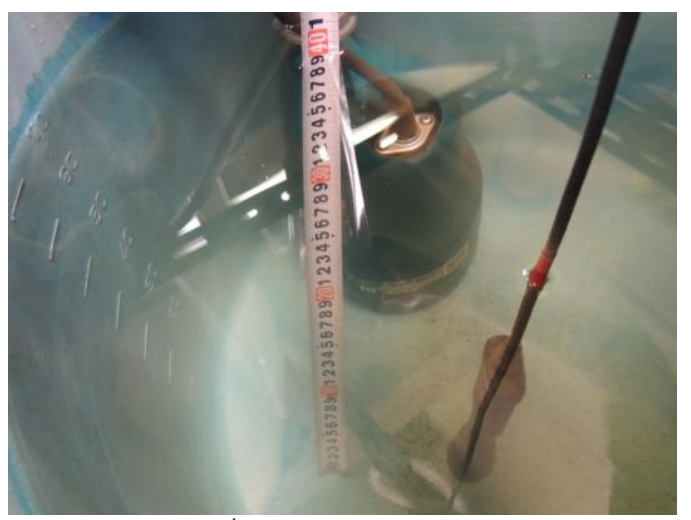

(a) $2^{\text {nd }}$ water in Tank 2 , last day

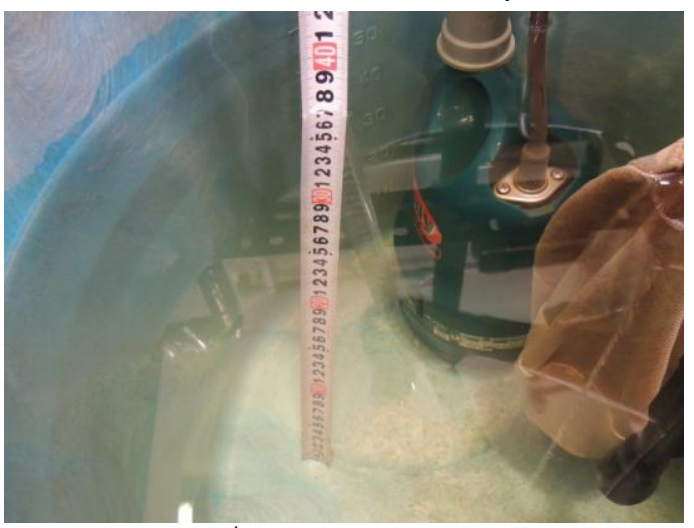

(b) $2^{\text {nd }}$ water in Tank 3 , last day

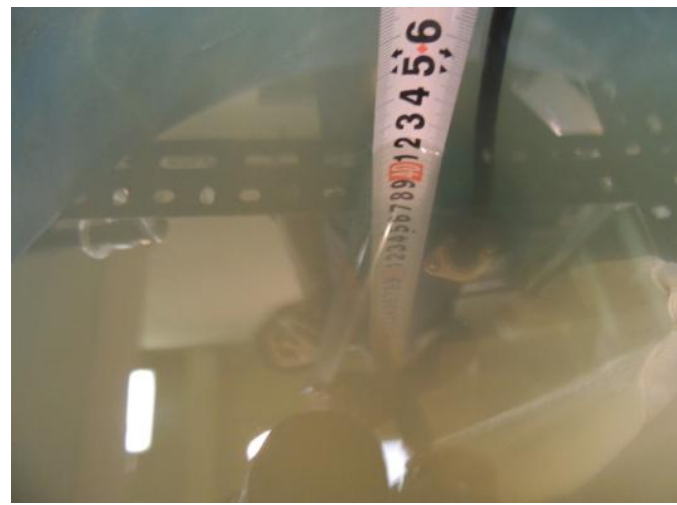

(c) $2^{\text {nd }}$ water in Tank 3 , first day

Fig. 9. Pictures of test waters after and before purification test. Upper figures in each cell: first day Lower figures in each cell: last day

\section{SUMMARY AND CONCLUSIONS}

Water purification tests were conducted twice against the deep water in Midorikawa-dam Lake in Kumamoto Pref., Japan. The effects of micro- bubbles periodically supplied by our multi-fluids-mixer and the Eco-Bio-Ring including aerobic bacteria (Bacillus bacterium) on the purification were studied, and the followings were clarified:

1) The bubbling rate of 1.0 or $2.0 \mathrm{~L} / \mathrm{min}$ was enough to increase dissolved oxygen in water, DO. Larger bubbling rate made the bubble size larger and ineffective. Even at $Q_{G}=1.0 \mathrm{~L} / \mathrm{min}, \mathrm{DO}$ value of the water in $80 \mathrm{~L}$ tank could be raised up to a saturation value within $30 \mathrm{~min}$.

2) BOD could be decreased from $46 \mathrm{mg} / \mathrm{L}$ to $6-10 \mathrm{mg} / \mathrm{L}$ within ten days depending on the bubbling rate and/or with and without the Eco-Bio-Ring.

3) COD could be decreased from $10 \mathrm{mg} / \mathrm{l}$ to $4-6 \mathrm{mg} / \mathrm{l}$.

4) The turbidity could be decreased from $1.5 \mathrm{mg} / \mathrm{l}$ (PSL) to 0 .

5) The Eco-Bio-Ring was effective to speed up the purification, especially in turbidity.

\section{ACKNOWLEDGMENT}

The authors wish to appreciate Mr. D. Kajiwara very much, undergraduate students in those days at Kumamoto University, for their experimental cooperation. The appreciations are also for both Mrs. K. Sakamoto and Mr. T. Sakamoto, the president of Big Bio Co. Ltd., Japan, and the head of a fishermen's union in Midorikawa area respectively, for their financial support and useful advices, and also for Mr. T. Shimoda, the head of Midorikawa-dam management office of the Japanese Ministry of Land, Infrastructure, Transport and Tourism, for giving us the test water.

\section{REFERENCES}

[1] T. Ueyama and M. Miyamoto, World of Micro-bubbles - Cooperative Action of Water and Gas, Tokyo: Kougyou-tyousakai, 2006.

[2] H. Kato, K. Miura, H. Yamaguchi, and M. Miyanaga, "Experimental study on microbubble ejection method for frictional drag reduction," $J$. of Marine Science and Technology, vol. 3. pp. 122-199, September 1998.

[3] H. Ohnari, T. Saga, K. Watanabe, and K. Maeda, "High functional characteristics of micro-bubbles and water purification," Resources Processing, vol. 46, pp. 238-244, December 1999.

[4] M. Takahashi, T. Kawamura, Y. Yamamoto, H. Ohnari, S. Himuro, and H. Shakutsui, "Effect of shrinking microbubble on gas hydrate formation," J. of Physical Chemistry, vol. 107, pp. 2171-2173, March 2003.

[5] E. Unger, T. O. Matsunaga, P. A. Schumann, and R. Zutshi, "Microbubbles in molecular imaging and therapy," MEDICAMUNDI, vol. 47, pp. 58-65, April 2003.

[6] K. Terasaka, A. Hirabayashi, T. Nishino, S. Fujioka, and D. Kobayashi, "Development of microbubble aerator for waste water treatment using aerobic activated sludge," Chemical Engineering Science, vol. 66, pp. 3172-3179, July 2011.

[7] N. Tamura, K. Fujiwara, S. Uesawa, and Y. Abe, "Development of non-chemical micro-bubble washing technology using a Venturi tube," Japanese J. Multiphase Flow, vol. 27, pp. 577-186, March 2014.

[8] M. Sadatomi, A. Kawahara, K. Kano, and A. Ohtomo, "Performance of a new micro-bubble generator with a spherical body in a flowing water tube," Experimental Thermal and Fluid Science, vol. 29, pp. 615-623, June 2005.

[9] A. Kawahara, M. Sadatomi, F. Matsuyama, H. Matsuura, M. Tominaga, and M. Noguchi, "Prediction of micro-bubble dissolution characteristics in water and seawater," Experimental Thermal and Fluid Science, vol. 33, pp. 883-894, July 2009.

[10] M. Sadatomi, A. Kawahara, H. Matsuura, and S. Shikatani, "Micro-bubble generation rate and bubble dissolution rate into water by a simple multi-fluid mixer with orifice and porous tube," Experimental Thermal and Fluid Science, vol. 41, pp. 23-30, September 2012

[11] M. Sadatomi and A. Kawahara, "Fluids mixer and fluids mixing method," Japanese Patent, no. 5103625, October 12, 2012.

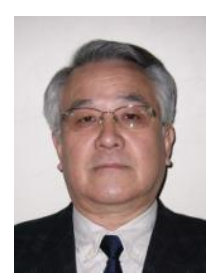

M. Sadatomi received the master degree of engineering from Kumamoto University, Japan in 1976 and became a research assistant in the same university. He received the doctor degree of engineering in from Kyushu University, Japan in 1986. Now, he is a professor of the Dept. of Advanced Mechanical Systems, Graduate School of Science and Technology at Kumamoto University, and also the Kyushu branch president of the Japan Society of Mechanical Engineers. His specialty is fluids engineering, especially multi-phase flow in power and environmental engineering. 
A. Kawahara received the master degree of engineering from Kumamoto University, Japan in 1990 and became a research assistant in the same university. He received the doctor degree of engineering from Kumamoto University in 1998. Now, he is an associate professor of the Dept. of Advanced Mechanical Systems, Graduate School of Science and Technology at Kumamoto University. His specialty is fluids engineering concerned with multiphase flow, especially in micro and mini channels.

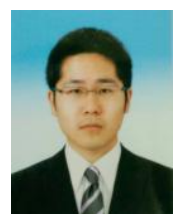

K. Kurogawa received the master degree of engineering from Kumamoto University, Japan in 2014 with the supervision by Prof. M. Sadatomi and Prof. A. Kawahara. Now, he is an engineer of Mitsuwa Electronic Co., Ltd.

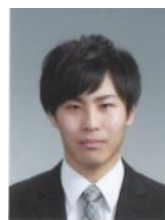

T. Akasaki is a master course student of Graduate School of Science and Technology at Kumamoto University. His research theme now is "Water purification and carbon dioxide dissolution in water using micro-bubbles". 